ISBN- 978-93-86878-17-5

13th Pattaya International Conference on Arts, Business, Education, Humanities and Social Sciences

(ABEHSS-18)

Pattaya (Thaialnd) May 31- June 1, 2018

\title{
The Role of Women in Politics of India \& Thailand in the 21st Century
}

\author{
Prof. Mamta Chandrashekhar D Lit and Yashita Chandrashekhar \\ Department of Political Science, MJ.B. Government Girls P.G. College, India
}

\begin{abstract}
This research work will highlight some of the key issues that concerned with The "The Role of Women in Politics of India and Thailand in the 21st Century " As women is a center part of a society even though political status of a woman depends on the social and political system of a contry. Women in Thailand were among the first women in Asia who were granted the right to vote in 1932. Now, after May 2014 what is the role of the women in politics? Indian women have been facing the Doubled prejudice sing long in the society which influence in the politics. At present are Thai women also facing the same? This kind of issues will be analysis in this research paper. Women have been in the higher posts in the politics $n$ government in the both countries. They participate in parliament and political parties. There are many provisions in constitution to protect their rights too. After that are they underrepresented in the politics? What is the role of women in the politics in the both countries? Is it satisfactory or there should be some change to empower a women politically? After identified the issue some suggestions will be given in this research paper. The issues of this topic are crucial as far as running the affairs of a particular country is concerned. This research work will encourage and inspire to establish some new aspects for the women of India and Thailand in the politics in the 21st century.
\end{abstract}

Keywords: Politics, Doubled prejudice, societies, women, discriminations.

\section{Introduction}

The 21st century has seen many changes in all over the world in every field. In the changing nature of sociopolitical and economical scenario women's status has also changed. Globalization, liberalization and urbanization play an important role in the transformation. After that the goal of gender parity throughout the world remains unfulfilled, and particularly so in the political arena. Despite some progress made in various parts of Asia, the ability of women to participate as policymakers in the political process remains limited. The socio political circumstances may be different but human dignity is a major aspect of life. Politics is a highest activity in which male and female can be taken part as a voter, activism or Member of Parliament or government sector. Problem created when the gender discrimination take place in the society as well as politics.

\section{Objectives}

- To know the role of the women in Indian politics.

- To know the role of the women in politics of Thailand

- To know the comparison between both countries.

- To analyze the Impact of Constitutional \& Legal Provisions on the Women's political Status.

- To know the practical aspects of woman's political status.

- To know the problems and perspective.

- To know the solution. 


\section{Methodology}

As it is a theory based work so the study has attempted to provide an analysis based facts. The information for this baseline report was primarily collected from secondary sources. Then the data analysis and tabulated as they required.

\section{Result/ Findings}

This research work finds that there are so many provisions for women in both countries. Several Constitutional provisions, laws and regulations are existed in the society for women. According constitution, women are legal citizens of the country and have equal rights with male. So women have got the right to vote 1932 in Thailand and 1950 in India. Women have adorned high offices including that of the President, Prime minister, Speaker of the Lok Sabha and Member of Parliament. Due to the 73rd Constitutional Amendment Act 1992 and the 74th Constitutional Amendment Act, 1993 woman empowered in local level government bodies.

In second hand the picture of women's role in politics in is very differ in on the canvas. A detailed investigation of 193 countries in early 2017 by the Inter Parliamentary Union presented some interesting facts about the representation of women in the Lower (or only) house of Parliament. India, the world's largest 'democracy', is ranked 148th with a pathetic show of 12.8 percent and 2012 Thai women were 17.8. Now this is also remarkable that the situation of women have turning points according to social-political system. .

\section{Women in Indian Politics}

In modern India, women have held high offices including that of the President,Prime Minister, Speaker of the Lok Sabha, Leader, Union Ministers, Chief Ministers and Governors. Pratibha Devi Singh Patil is the only woman to hold the office first. She served as the 12th President of India from 2007 to 2012. Smt. Indira Gandhi was first female prime minister of India. She served as Prime Minister from 1966 to 1977 and then again from 1980 until her assassination in 1984, making her the second-longest-serving Prime Minister after her father. Jawaharlal Nehru's first cabinet had only one woman minister - Rajkumari Amrit Kaur who was given the charge of Health Ministry. At present there are seven women out of a team of 23 ministers of the new cabinet headed by Narendra Modi. The Parliament is the supreme legislative body of the Republic of India. Parliament is composed of the President of India, the Rajya Sabha (Council of States) and the Lok Sabha (House of the People).

A governor is the constitutional head of each of the twenty-nine states. Sarojini Naidu was the first female to become the governor of an Indian state. She governed Uttar Pradesh from 15 August 1947 to 2 March 1949. Her daughter, Padmaja Naidu, is the longest-serving governor with 11-year tenure in West Bengal. Anandiben Patel was recently appointed as the second woman governor of Madhya Pradesh.. Sixteen women have served as the chief minister of an Indian state. Currently, three are in office - Vasundhara Raje, Mamata Banerjee and Mehbooba Mufti. Of the thirteen states to have been headed by a female chief minister, only three-Delhi, Tamil Nadu and Uttar Pradesh-have had two woman premiers After the establishment of women's reservations, political participation went from $4-5 \%$ to $25-40 \%$ among women, and gave millions of women the opportunity to serve as leaders in local government. The participation of women in voting day by day is increasing in India. 
Table - 1 Representation of Women in Lok Sabha 1952-2014

\begin{tabular}{lccc}
\hline \multicolumn{1}{c}{ Lok Sabha } & $\begin{array}{c}\text { Total no. of seats } \\
\text { (Elections Held) }\end{array}$ & $\begin{array}{c}\text { No. of Women Members } \\
\text { who won }\end{array}$ & \% of the Total \\
\hline First (1952) & 489 & 22 & 4.4 \\
Second (1957) & 494 & 27 & 5.4 \\
Third (1962) & 494 & 34 & 6.7 \\
Fourth (1967) & 523 & 31 & 4.9 \\
Fifth (1971) & 521 & 22 & 3.4 \\
Sixth (1977) & 544 & 19 & 5.1 \\
Seventh (1980) & 544 & 28 & 8.1 \\
Eighth (1984) & 544 & 44 & 5.3 \\
Ninth (1989) & 529 & 28 & 7.0 \\
Tenth (1991) & 509 & 36 & 7.4 \\
Eleventh (1996) & 541 & $40^{*}$ & 8.0 \\
Twelfth (1998) & 545 & $44^{*}$ & 8.1 \\
Thirteenth (1999) & 543 & $48^{*}$ & 10.9 \\
Fourteenth (2004) & 543 & $45^{*}$ & 11.2 \\
\hline Fifteenth (2009) & 543 & 59 & 61 \\
Sixteenth (2014) & 543 & 5.2 & \\
\hline
\end{tabular}

(Source: Election Commission of India) * Including one nominated member.)

\section{Women in Thailand Politics}

The beautiful Thailand is the only country in south-east Asia that has never been colonized by Western countries. The monarchy and the military have helped to shape its society and politics. Since 22 May 2014, the 2007 constitution was revoked, and Thailand has been under the rule of a military organization called National Council for Peace and Order (NCPO), which has taken control of the national administration. Women in Thailand were among the first women in Asia who were granted the right to vote in 1932. They are underrepresented in Thai politics. Yingluck Shinawatra, a woman, was prime minister from 2011 to 2014. Yingluck Shinawatra was prime minister of Thailand from 2011 to 2014. She was the first woman in the country to hold that office. At present Thai Prime Minister Prayuth Chan-ocha has 36 members, and the latest changes cut members from the army to nine, including Prayuth, from12. There are no women at all in the cabinet. The Senate of the Kingdom of Thailand is the upper house of the National Assembly of Thailand (Thailand's legislative branch). Orapin Chaiyaka is the first woman elected to a post in the Parliament of Thailand, on June 5, 1949 after that the number of female senators has raised to 25 , although proportionately it remains at a low $16.4 \%$. For the elected senators the number of women elected has risen to 14 , or. $17.9 \%$ and for the appointed senators the figure is 11 , or 14.9 .

In local government, substantial changes occurred when the Local Administration Act allowed women to take up the posts of village head and sub-district head. In 2009, 9.33\% of elected provincial governors (there are 76 Provincial Administration Organisations) and 4.8\% of elected Tambon (district) governors were women (there are 6,060 Tambon (districts).Department of Local Administration, Ministry of the Interior In 1932 Thailand was changed from the Absolute Monarchy to Constitutional Monarchy and in the first constitution of 1933 women were given the same voting rights as men, acquired the rights to vote. In the 2006 general elections $52.22 \%(12,000,372)$ of voters were female, $47.78 \%$ were $(10,972,706)$ male. In the latest election for Governor of Bangkok, in $2009,54.56 \%(1,435,842)$ of voters were female, $45.37 \%(1,193,964)$ male. 
Table 2: Comparison

\begin{tabular}{lll}
\hline & Women in India & Women In Thailand \\
\hline Right to vote & 1947 & 1932 \\
First Prime Minister & 1966 & 2011 \\
First Minister & 1947 & 1949 \\
Average \% in Parliament & 9.32 & 11.9 \\
In local Government & Reserved seats & None \\
\hline
\end{tabular}

The low number of women in politics in Thailand and India reflects a long tradition in which women have looked after the household while public matters have been taken care of by the heads of households typically men. In the past this would also have been affected by women's inferior levels of education. Nowadays, however, women's standard of education is more or less equal to men's so this can no longer be considered a barrier. To make effective role in Politics women should be empowered in various way of life.

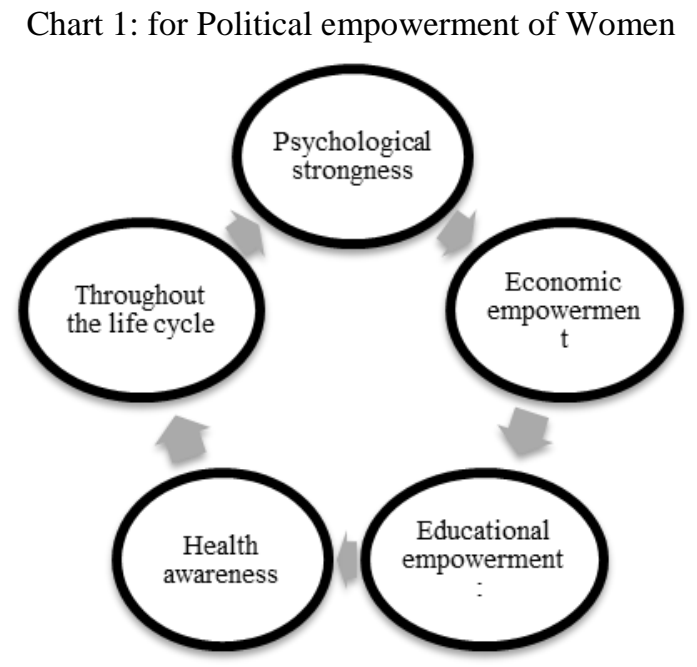

\section{Suggestions}

There are some suggestions:

1. To get Political opportunity women have to motivate by political parties and governmental agencies.

2. Women must be careful while using right to vote.

3. There is a need to refresh the social systems.

4. Education must be compulsory for every woman.

5. Must be remembering that women are also human being.

6. Be aware about the constitution, legal provisions, human right etc.

7. Women should be aware towards their rights.

8. Some skill development programme may be useful for women.

9. Focused on Implementation level. Awareness is the major part of the implementation. 


\section{Conclusion}

The research paper come to the conclusion that the role of women the in the politics of India and Thailand is in initial level. Still there is a need to establish yet. Due to the gender discrimination and social and family responsibility women didn't come in the politics. Women in India continue to face disparities in access and control over resources. Women are underrepresented in Thai politics too. The role of women in Thailand's national politics and development have not yet been fully established The courage, struggle, and persistence of today's women against suppression, exploitation and torture have the power to ensure that the future generations will not have to face the bleak reality in both countries.

\section{References}

[1] Augustine, P,A. Social Equality in Indian Society: the Elusive Goal, Concept Publishing Company, New Delhi. (1991

[2] Basu, D.D.’The introduction to Indian Constitution" New Delhi, Anmol publication Pvt. Ltd., New Delhi. (INDIA)

[3] Bernstein, Richard. Variations on a theme: Thai women and foreign husbands, Letter from Thailand, Asia-Pacific, The New York Times, August 12, 2007

[4] Chatterjee, Soma A.(1988)The Indian Women Search for an Identity, Vikash Publishing House, New Delhi.(INDIA)

[5] Chaurasia, Dr. B. P.(1992) Women's Status in India(Policies and Programs) Chugh Publications, Allahabad (INDIA

[6] Dash, L.N.(1993) Women ,Family Life and Rural walfare, Manak Publications Pvt. Ltd,

[7] Devasia, Leelamma and Dvasia, V.V.(1992) Women in India: Equality, Social Justice and Development, Ashish Publishing House New Delhi.

[8] Devendra, Kiran(1994) Changing Status of Women in India, Vikash Publishing House, New Delhi. (INDIA)

[9] Iwanaga, Kazuki. Women in Politics in Thailand, Working Paper No. 14, Centre for East and South-East Asian Studies, Lund University, Sweden, 2005

[10] Kaur Rajender and Shingh Ranjit [1992] Development Program for Rural women, Vohra Publishers and Distributors, Allahabad.

[11] Lipson, Leslie: The Great Issues of Politics, (Bombay 1973), and p.145.

[12] Michael H. Nelson (ed.), "Consolidating Thai Democracy," in Thailand's New Politics: KPI Yearbook 2001. Bangkok: King Prajadhipok’s Institute. Bystydzienski, Jill M. (1992).

[13] Pruthi,Raj and Sharma,BelaRani(1994) Encyclopedia of Women Society and Culture, Vol-1. 